\title{
Contents to Volume 57 (2017)
}

An Unsere Leserinnen und Leser/To Our Readers 1

\author{
NACHRUF/OBITUARY
}

Sadik Jalal Al-Azm November 7, 1934 (Damascus) - December 11, 2016 (Berlin) $\quad 3-6$

Stefan Wild

AUFSÄTZE/ARTICLES

New Trends in Islamic Legal Theory: Maqāṣid al-Sharī'a as a New Source of Law? $\quad 7-32$

Felicitas Opwis

A Perverted Balance: Modern Salafism between Reform and Jihad 33-66 Itzchak Weismann

Emergence of the Sadrian Paradigm: Historical Account of the Reception of Mullā Șadrā's School of Thought in Later Islamic Philosophy $\quad 67-93$

Mahdi Golparvar-Roozbahani

Muslim Female Religious Authority in Russia: How Mukhlisa Bubi Became the First Female Qā $\bar{c} \bar{\imath}$ in the Modern Muslim World $\quad$ 135-61

Rozaliya Garipova

From 1917 to 1937: The Mufti, the Turkologist, and Stalin's Terror $\quad 162-91$ Michael Kemper

Coded Language Among Muslim Activists: Salafīs and the Prophet's Sermon of Necessity $\quad 192-222$

Alexander Thurston

Middle Eastern Patriarchy in Transition $\quad 265^{-77}$

Rania Maktabi and Brynjar Lia (guest editors)

Broken Walls: Challenges to Patriarchal Authority in the Eyes of Sudanese Social Media Actors 278-302

Albrecht Hofheinz 
Beyond Preaching Women: Saudi Dā'iyāt and Their Engagement in the Public Sphere $\quad 303^{-28}$

Laila Makboul

Islamist Women as Candidates in Elections: A Comparison of the Party of Justice and Development in Morocco and the Muslim Brotherhood in Egypt 329-59

Katarína Škrabáková

Agents of Change: How Islamist Women Activists in Israel Are Challenging the Status Quo $\quad 360-85$

Tilde Rosmer

Nationalist Patriarchy, Clan Democracy: How the Political Trajectories of Palestinians in Israel and the Occupied Territories Have Been

Reversed 386-403

Dag H. Tuastad

Kurdish Women in Rojava: From Resistance to Reconstruction 404-28

Pinar Tank

The Jihādì Movement and Rebel Governance: A Reassertion of a Patriarchal Order? 429-50

Brynjar Lia

Reluctant Feminists? Islamist MPs and the Representation of Women in Kuwait after $2005 \quad 451-79$

Rania Maktabi

LITERATUR/BOOK REVIEWS

Bekim Agai, Olcay Akyildiz \& Caspar Hillebrand (eds.): Venturing beyond Borders. Reflections on Genre, Function, and Boundaries in Middle Eastern Travel Writing $95^{-98}$

Anja Pistor-Hatam

Al-Azm, Sadik J.: Secularism, Fundamentalism, and the Struggle for the Meaning of Islam. Collected Essays on Politics and Religion. With a Foreword by Stefan Wild. Vol. 1: On Fundamentalisms, Vol. 2: Islam. Submission and Disobedience, Vol. 3: Is Islam Secularizable? Challenging Political and Religious Taboos 99-103

Alexander Flores

Johann Büssow \& Khaled Safi: Damascus Affairs. Egyptian Rule in Syria through the Eyes of an Anonymous Damascene Chronicler, 1831-1841. Translation and Parallel Edition of Two Manuscripts by Johann Büssow and 
Khaled Safi. In Collaboration with Sarah Büssow-Schmitz and with a Preface by Ingeborg Huhn 104-07

Ralf Elger

Josef van Ess: Die Träume der Schulweisheit: Leben und Werk des 'Alī b. Muḥammad al-Ğurğānī (gest. 816/1413) 108-11

Jan-Peter Hartung

Markus Friedrich \& Alexander Schunka (eds.): Orientbegegnungen deutscher Protestanten in der Frühen Neuzeit $\quad 112-15$

Ralf Elger

Robert Gleave (ed.): Books and Bibliophiles. Studies in Honour of Paul Auchterlonie on the Bio-Bibliography of the Muslim World 116 Hinrich Biesterfeld

Rüdiger Lohlker: Islamisches Recht $\quad 117-20$

Angelika Brodersen

Mohammad Maraqten: Altsüdarabische Texte Auf Holzstäbchen. Epigraphische und kulturhistorische Untersuchungen 121-23

BarbaraJändl

Silvia Martens: Muslimische Wohltätigkeit in der Schweiz $\quad 124-26$

Hüseyin I. Çiçek

Rudolf Smend in Zusammenarbeit mit Peter Porzig und Reinhard Müller (eds.): Julius Wellhausen: Briefe 127-29

Henning Trüper

Sibel Zandi-Sayek: Ottoman Izmir. The Rise of a Cosmopolitan Port (18401880) 130-33

Nora Lafi

Seema Alavi: Muslim Cosmopolitanism in the Age of Empire $\quad 223^{-26}$

Simon Wolfgang Fuchs

Ramzi Baalbaki: The Arabic Lexicographical Tradition. From the 2nd/8th to the 12th/18th Century 227-29

Vivian Strotmann

Kees van Dijk and Nico J.G. Kaptein (eds.): Islam, Politics and Change. The Indonesian Experience after the Fall of Suharto $\quad 230-32$

Fritz Schulze

Andreas Görke and Johanna Pink (eds.): Tafsīr and Islamic Intellectual History. Exploring the Boundaries of a Genre $\quad 233^{-} 36$

Angelika Brodersen

Ousman Murzik Kobo: Unveiling Modernity in Twentieth-Century West African Islamic Reforms $\quad 237-40$

Louis Brenner 
David Motadel (ed.): Islam and the European Empires $\quad 241-44$

Rainer Brunner

Lloyd Ridgeon (ed.): The Cambridge Companion to Sufism $\quad 245^{-48}$

Angelika Brodersen

Tilman Seidensticker: Islamismus. Geschichte, Vordenker,

Organisationen $\quad 249-52$

Angelika Brodersen

Suha Taji-Farouki (ed.): The Qur'an and Its Readers Worldwide. Contemporary Commentaries and Translations $\quad 253-57$

Angelika Brodersen

Mustafa Tuna: Imperial Russia's Muslims: Islam, Empire and European

Modernity, 1788-1914 258-6o

Michael Kemper

Sophia Vasalou: Ibn Taymiyya's Theological Ethics 261-64

Farid Suleiman 